\title{
FATWA TENTANG HADIAH DI LEMBAGA KEUANGAN SYARIAH
}

\author{
Jaih Mubarok \\ Fakultas Syariah dan Hukum UIN Sunan Gunung Djati \\ Jl. Raya Cipadung, No. 105, Cibiru, Bandung, 10614 \\ e-mail:jaihmubarok@yahoo.com \\ Hasanudin \\ Fakultas Syariah dan Hukum UIN Syarif Hidayatullah \\ Jl. Ir. H. Juanda No. 95 Ciputat, Jakarta, 15419 \\ e-mail: umafaz@yahoo.co.id \\ Yulizar D. Sanrego \\ Sekolah Tinggi Ekonomi Islam Tazkia \\ Jl. Ir. H. Djuanda No. 78, Sentul City, Bogor, 16810 \\ e-mail: senapate@yahoo.com
}

\begin{abstract}
Abstrak: Kajian ini dilakukan untuk menggali hukum tentang pemberian hadiah oleh Lembaga Keuangan Syariah (LKS) kepada nasabah berupa cindera mata maupun hadiah yang bersifat material pada saat pembukaan rekening dengan cara undian. Akad wadî‘ $a h$ dalam produk penghimpunan dana LKS secara substantif sama dengan akad qardh karena di dalamnya terkandung izin penggunaan objek yang dititipkan. Karena itu, akad wadî‘ $a h$ tersebut termasuk domain akad tabarru'. Sedangkan akad mudhârabah termasuk akad bisnis yang dikategorikan sebagai akad mu'âwadhat/ tijârî. Jâ'izah tasjî́iyah juga sama kedudukannya dengan akad mudhârabah, yaitu termasuk domain mu'âwadhat. Karena itu, penulis menyimpulkan bahwa tidak relevan penggunaan jầizah tasjîtiyah dalam memasarkan produk penghimpunan dana LKS yang menggunakan akad wadî‘ $a h$ atau qardh. Sebaliknya, jầizah tasjî́iyah layak dipertimbangkan untuk digunakan dalam mempromosikan produk LKS yang menggunakan akad yang termasuk domain mu'âwadhat.
\end{abstract}

\begin{abstract}
Personal Legal Opinion on Present in Syari'ah Financial Institution. This study is aimed at deducting legal ruling of material gift or present offered by the Syari'ah financial institution (LKS) for their clients at the time of opening account by way of lottery. Wadî́ah contract in collecting LKS funds is substantially similar to that of qardh contract because permission to usufruct the stored object is inherent in the contract, therefore such wadî́ $a$ h contract is included in the domain of tabarru'. Mudhârabah contract, on the other hand, comprises business contract which is categorized
\end{abstract}


as mu'âwadhat or tijârî contract. Jầizah tasjîi iyah also have the same status as mudhârabah contract which is included in the mu'âwadhat domain. As such, the authors conclude that it is irrelevant to use jầizah tasjî́iyah in selling the product of LKS fund collection with wadî‘ $a h$ or qardh contract. Conversely, jầizah tasjî́'iyah is worthy of considering to be used in promoting LKS product using contract that comprises in the mu'âwadhat sphere.

Kata Kunci: hadiah, fatwa, mu'âwadhat, qardh, wadî‘ah

\section{Pendahuluan}

Lembaga Keuangan Syariah (LKS), termasuk perbankan syariah, merupakan institusi bisnis yang di antara karakternya berorientasi pada keuntungan (profit oriented). ${ }^{1}$ Keuntungan yang diharapakan oleh Lembaga Keuangan Syariah berasal dari tiga kegiatan bisnis yang dilakukannya, yaitu penghimpunan dana (funding), penyaluran dana (financing) dan jasa. ${ }^{2}$ Dalam rangka mendapatkan keuntungan dimaksud, Lembaga Keuangan Syariah melakukan pemasaran (marketing), promosi, ${ }^{3}$ dan/atau kegiatan lainnya yang berupa pemberian hadiah/cindera mata pada saat pembukaan rekening, dan undian yang bersifat material seperti hadiah kendaraan, dan/atau perjalanan ibadah haji/umrah. ${ }^{4}$

Kajian ini dilakukan untuk menggali dan menemukan hukum tentang pemberian hadiah oleh Lembaga Keuangan Syariah kepada nasabah yang berupa cindera mata pada saat pembukaan rekening, dan hadiah yang bersifat material berupa kendaraan dan/atau perjalanan haji/umrah yang diproses dengan cara undian. Hasil kajian ini diharapkan dapat membantu pihak-pihak terkait (industri dan regulator) dalam hal kejelasan hukum pemberian hadiah dalam promosi Lembaga Keuangan Syariah dari aspek syariah.

\section{Fatwa Terkait Lembaga Keuangan Syariah dan Produknya}

Fatwa pada prinsipnya termasuk instrumen hukum Islam. ${ }^{5}$ Muhammad Atho Mudzhar,

${ }^{1}$ Dalam kitab fikih dijelaskan antara untung (profit/ribh) dan rugi (khasarah). Untung adalah pertambahan modal setelah di-tasharruf-kan; sedangkan rugi adalah berkurangnya modal setelah di-tasharruf-kan. Lihat Muhy al-Dîn al-Qurrah Daghi, Buhûts fî al-Bunûk al-Islâmî (Beirut: Dâr al-Basya'ir al-Islâmiyah, 2009), h. 11.

${ }^{2}$ Lihat Adiwarman A. Karim, Bank Islam: Analisis Fiqih dan Keuangan (Jakarta: Raja Grafindo Persada, 2010), h. 339-355; Muhammad Imran Ashraf Usmani, Meezanbank's Guide to Islamic Banking (Karachi: Darul Ishaat, 2002), h. 87-163.

${ }^{3}$ Lihat Khalid Abd Allah al-Mushlih, al-Hawâfiz al-Tijâriyah al-Taswîqiyah wa Ahkâmuhâ fi al-Fiqh al-Islâmi (t.t.p.: t.p. t.t.), h. 9.

${ }^{4}$ Pemasaran merupakan kegiatan yang sangat penting dalam bisnis. Lihat antara lain Ricky W. Griffin dan Ronald J. Ebert, Bisnis, Vol. II (Jakarta: Indeks, 2006), h. 89-125.

${ }^{5}$ Hukum Islam seringkali dipahami sebagai terjemahan dari term fikih (al-fiqh), al-syarî‘ah, al-h̆ukm al-Islâmi, Syari‘a Law, dan Islamic Law. Busthanul Arifin mengatakan bahwa hukum Islam 
Guru Besar Hukum Islam pada UIN Syarif Hidayatullah Jakarta, yang memperkenalkan empat instrumen hukum Islam, yaitu fikih, fatwa, qanun, dan qâdha', ${ }^{6}$ masing-masing memiliki karakter dan kekhasan yang ragam. Ma'ruf Amin dalam pidato ilmiah pada

adalah kata ganti dari dua istilah yaitu al-syarî' at dan al-fiqh. Penggantian kata ini, jelas Busthanul Arifin, telah menimbulkan kekacauan pengertian dan menimbulkan kesalahpahaman di masyarakat. Lihat Amrullah Ahmad (ed.), Prospek Hukum Islam dalam Kerangka Pembangunan Hukum Nasional di Indonesia: Sebuah Kenangan 65 Tahun Prof. Dr. H. Busthaul Arifin, SH (Jakarta: IKAHA dan Gema Insani Press, 1994), h. 61; dan Joseph Schacht, An Introduction to Islamic Law (Oxford: Oxford University Press. 1964). N.J. Coulson menyebutnya sebagai Islamic law dan Islamic Jurisprudence. Lihat N.J. Coulson, A History of Islamic Law (Edinburgh: Edinburgh University Press. 1991), dan N.J. Coulson, Conflicts and Tensions in Islamic Jurisprudence (Chicago \& London: The University of Chicago Press. 1969). Setiap terminologi memiliki kerangka pemikiran tersendiri. Karena itu, ulama dalam berbagai tulisan dan forum telah berusaha ikut serta menjelaskan terminologi-terminologi tersebut sehingga antara yang satu dengan yang lainnya dapat dibedakan dan ditempatkan secara proporsional. Ibrahim Hosen (mantan ketua Komisi Fatwa MUI) yang turut serta menjelaskan hal ini. Menurutnya, hukum Islam itu ada dua. Pertama, hukum Islam yang secara langsung dan tegas ditetapkan oleh Allah melalui dalil qath 'iy. Kedua, hukum Islam yang ditetapkan pokok-pokoknya saja dan ditetapkan oleh Allah melalui dalil zhanniy. Hukum Islam yang pertama disebut syarî́ah; Syariah diyakini bersifat konstan, sempurna, dan tetap berlaku universal (sepanjang zaman), tidak mengenal perubahan dan tidak dapat disesuaikan dengan situasi dan kondisi. Sedangkan hukum Islam yang kedua disebut fikih. Fikih bersifat dinamis dan fleksibel, tidak bersifat universal, dan dapat mengalami perubahan. Lihat Ibrahim Hosen, "Fungsi dan Karakteristik Hukum Islam dalam Kehidupan Umat Islam," dalam Amrullah Ahmad (ed.), Prospek Hukum Islam dalam Kerangka Pembangunan Hukum Nasional di Indonesia: Sebuah Kenangan 65 Tahun Prof. Dr. H. Busthaul Arifin, SH (Jakarta: IKAHA dan Gema Insani Press, 1994), h. 128; dan Oyo Sunaryo, "Hukum Kewarisan Islam: Formulasi Baru tentang Kewarisan Islam dalam Tata Hukum Indonesia," dalam al-Tadbir, Vol. I, No. 3, 2000, h. 100.

${ }^{6}$ Pertama, fikih sebagai jenis produk pemikiran hukum Islam bersifat menyeluruh dan meliputi semua aspek hukum Islam, sehingga di antara cirinya cenderung kebal pada perubahan karena revisi atas sebagiannya dianggap mengganggu keutuhan isi keseluruhannya. Dalam sejarah terbukti bahwa beberapa buku fikih telah diperlakukan sebagai kitab undang-undang, meskipun ketika kitab-kitab fikih itu ditulis tidak dimaksudkan untuk diberlakukan secara umum di suatu negara. Kitab-kitab fikih ketika ditulis oleh pengarangnya tidak secara eksplisit disebut masa berlakunya, sehingga cenderung dianggap berlaku untuk sepanjang masa. Kedua, fatwa, yaitu produk pemikiran hukum Islam yang bersifat kasuistik karena merupakan respons atau jawaban terhadap pertanyaan yang diajukan oleh peminta fatwa. Fatwa tidak mempunyai daya ikat, dalam arti bahwa peminta fatwa tidak harus mengikuti fatwa yang diberikan kepadanya. Demikian pula masyarakat luas tidak harus terikat dengan fatwa itu, karena fatwa seorang ulama di suatu tempat bisa saja berbeda dari fatwa ulama lain di tempat yang sama. Fatwa cenderung bersifat dinamis karena merupakan respons terhadap perkembangan baru yang sedang dihadapi masyarakat peminta fatwa; meskipun isi fatwa itu sendiri belum tentu dinamis. Ketiga, qanun, yaitu produk pemikiran hukum Islam yang berupa peraturan perundang-undangan di negaranegara Islam yang bersifat mengikat; bahkan daya ikatnya lebih luas dalam masyarakat. Pihak yang terlibat dalam perumusannya juga tidak terbatas pada kalangan ulama atau fukaha, tetapi juga para politisi dan cendekiawan lainnya. Masa berlaku peraturan perundang-undangan biasanya dibatasi, baik secara eksplisit maupun secara implisit. Keempat, qadha', yaitu keputusan-keputusan pengadilan agama; qadha' cenderung bersifat dinamis karena merupakan respon terhadap perkaraperkara nyata yang dihadapi masyarakat. Ciri keputusan pengadilan agama adalah tidak meliput semua aspek pemikiran hukum Islam seperti halnya fikih. Tetapi dari segi kekuatan hukumnya, ia lebih mengikat terutama bagi pihak-pihak yang bersangkutan. Lihat M. Atho Mudzhar, "Penerapan 
penganugerahan Gelar Doktor Kehormatan (Doctor Honoris Causa) dalam bidang Hukum Ekonomi Syariah, melanjutkan hubungan antara fikih dengan fatwa yang secara akademik mengutip pendapat ulama yang substansinya adalah bahwa fikih berarti pengetahuan tentang hukum syariah amaliah yang digali dari dalil-dalil yang bersifat rinci. Sedangkan fatwa adalah penjelasan hukum syariah kepada pihak yang menanyakannya (tabyîn alhukm syar'iy li-man sa'ala 'anhu), sedangkan al-Barazi menjelaskan bahwa fatwa adalah tabyîn al-ȟhukmi al-syar'iy 'an dalîl li-man sa'ala 'anhu. ${ }^{7}$

Dalam Pedoman Dasar dan Pedoman Rumah Tangga DSN-MUI dikenalkan institusi bisnis syariah, yaitu Lembaga Keuangan Syariah (LKS) yang berupa bank, dan LKS nonbank. LKS-bank dibedakan menjadi tiga. Pertama. Bank Umum Syariah (BUS), yaitu bank yang secara penuh menjalankan bisnis dengan menerapkan sistem syariah. Kedua. Unit Usaha Syariah (UUS); yaitu bank konvensional yang memiliki unit yang menjalankan bisnis dengan menerapkan sistem syariah. Ketiga. Bank Pembiayaan Rakyat Syariah (BPRS), yaitu rural bank, bank yang cakupan dan wilayah bisnisnya relatif terbatas yang secara penuh menjalankan bisnis dengan menerapkan sistem syariah.

LKS-nonbank (sekarang diatur dan diawasi oleh Otoritas Jasa Keuangan [OJK] dikenal terminologi IKNB, yaitu Industri Keuangan non-Bank) di antaranya adalah. Pertama. Perasuransian Syariah (asuransi syariah dan reasuransi syariah), baik yang full syariah maupun yang masih unit syariah; yang menjalankan usaha di bidang asuransi umum maupun asuransi jiwa. Kedua. Reksadana Syariah. Ketiga. Pegadaian Syariah. Keempat. Multifinance Syariah. Kelima. Jakarta Futures Exchanges (JFX) Syariah. Keenam. Koperasi Syariah baik yang full syariah (antara lain Koperasi Baitul Mal wat Tamwil/KBMT) maupun yang berupa Unit Jasa Keuangan Syariah (UJKS). Ketujuh. Pegadaian Syariah. Kedelapan. Penjaminan Syariah. Kesembilan. Modal Ventura Syariah. ${ }^{8}$

Industri Keuangan Bank (IKB) adalah industri keuangan yang paling kompleks dari segi produk, baik menyangkut penghimpunan dana (funding) atau disebut juga simpanan (dari segi nasabah) dan penyaluran dana (financing), serta jasa. Dalam Undang-Undang Nomor 21 Tahun 2008 tentang Perbankan Syariah, bank syariah dibedakan menjadi tiga,

Pendekatan Sejarah Sosial dalam Hukum Islam," makalah disampaikan dalam acara diskusi yang diselenggarakan oleh Pusat Pengkajian UNISBA, di Bandung (8 Januari 1992), h. 2-4; dan M. Atho Mudzhar, "Fiqh dan Reaktualisasi Ajaran Islam," dalam Budhy Munawar-Rachman (ed.), Kontekstualisasi Doktrin Islam dalam Sejarah (Jakarta: Yayasan Wakaf Paramadina, 1994), h. 369-370.

${ }^{7}$ Maruf Amin, "Pembaharuan Hukum Ekonomi Syariah dalam Pengembangan Produk Keuangan Kontemporer (Transformasi Fikih Muamalat dalam Pengembangan Ekonomi Syariah)," Pidato Ilmiah pada Penganugerahan Gelar Doktor Kehormatan (Doctor Honoris Causa) dalam Bidang Hukum Ekonomi Syariah di Kampus UIN Syarif Hidayatullah Jakarta (5 Mei 2012), h. 7. Lihat juga Muhammad Fu'ad al-Barazi, Mas'ûliyat al-Fatwâ al-Syar'iyah wa Dhawâbituhâ wa Atsaruhâ fi Rasyad al-Ummah (t.t.p.: t.p. t.t.), h. 5-6; dan Nasrun Haroen (ed.), Ensiklopedi Hukum Islam, Vol. I (Jakarta: Ichtiar Baru van Hoeve. 2003), h. 326-328.

${ }^{8}$ Lihat Direktori Syariah Indonesia (Jakarta: Dewan Syariah Nasional MUI. t.t.). 
yaitu Bank Umum Syariah (BUS), Bank Pembiayaan Rakyat Syariah (BPRS), ${ }^{9}$ dan Unit Usaha Syariah (UUS), yaitu unit kerja dari kantor pusat Bank Umum Konvensional yang berfungsi sebagai kantor induk dari kantor atau unit yang melaksanakan kegiatan usaha berdasarkan prinsip syariah, atau unit kerja di kantor cabang dari suatu Bank yang berkedudukan di luar negeri yang melaksanakan kegiatan usaha secara konvensional yang berfungsi sebagai induk dari kantor cabang pembantu syariah dan/atau unit syariah. ${ }^{10}$

${ }^{9}$ Sebelum diberlakukannya Undang-Undang Nomor 21 tahun 2008 tentang Perbankan Syariah, BPRS adalah singkatan dari Bank Perkreditan Rakyat Syariah; setelah tahun 2008, kata Perkreditan diubah menjadi Pembiayaan. Hal ini penting untuk diketahui umum karena dalam Undang-Undang Nomor 7 Tahun 1992 tentang Perbankan (pasal 1 angka 12) didefinisikan bahwa kredit adalah penyediaan uang atau tagihan yang dapat dipersamakan dengan itu berdasarkan persetujuan atau kesepakatan pinjam meminjam antara Bank dengan pihak lain yang mewajibkan pihak peminjam untuk melunasi utangnya setelah jangka waktu tertentu dengan jumlah bunga, imbalan atau pembagian keuntungan. Hal yang sama juga ditegaskan kembali dalam UndangUndang Nomor 10 Tahun 1998 tentang Perubahan atas Undang-Undang Nomor 7 Tahun 1992 tentang Perbankan (pasal 1 angka 11) yang mendefinisikan kredit adalah penyediaan uang atau tagihan yang dapat dipersamakan dengan itu, berdasarkan persetujuan atau kespakatan pinjam meminjam antara Bank dengan pihak lain yang mewajibkan pihak peminjam untuk melunasi utangnya setelah jangka waktu tertentu dengan pemberian bunga. Karena itu, dalam terminologi kredit terkandung bunga; sedangkan bunga (baca: bunga uang) hukumnya haram karena termasuk riba nasi'ah. Lihat Muhammad Abû Zahrah, Buhuts fí al-Riba (Mesir: Dâr al-Buhuts al-'Ilmiyah. 1970), h. 36-48; Ahmad Azhar Basyir, Hukum Islam tentang Riba, Utang-Piutang, dan Gadai, Cet. 2 (Bandung: al-Ma'arif, 1983), h. 28; Mahmud Abu al-Saud, "Islamic View of Riba: Usury and Interest," dalam Syaikh Ghazali Syaikh Abod, et al. (ed.), An Introduction to Islamic Finance (Kuala Lumpur: Quill Publishers, 1992), h. 70-73; Thahir Abdul Muhsin Sulaiman, Menanggulangi Krisis Ekonomi secara Islam, terj. Anshori Umar Sitanggal (Bandung: al-Ma`arif, 1985), h. 282; Isa Abduh, Bunuk bila Fawa'id (Mesir: Dâr al-I' tisham, t.t.), h. 117-120; Muhammad Baqer Sadr dan Ayatullah Sayyid Mahmud Taleghani, Islamic Economics: Contemporary Ulama Perspective (Kuala Lumpur: Iqra', 1991), h. 9-10; M. Mohsen, "A Profile of Riba-Free Banking," dalam Mohammad Arief (ed.), Monetary and Fiscal Economics of Islam (Jeddah: International Centre for Research in Islamic Economics, King Abdulaziz University, 1982), h. 187-210; A. Hassan, Soal-Jawab tentang Berbagai Masalah Agama, Juz II, Cet. 10 (Bandung: Diponegoro, 1988), h. 678; Aswita Taizir, "Muhammad Abduh and The Reformation of Islamic Law," (Thesis McGill University, 1994), h. 93-94; PP Muhamadiyah, Himpunan Putusan Tarjih (Yogyakarta: Pengurus Pusat Muhammadiyah Majlis Tarjih, t.t.), h. 304-305; Hussain Hamid Hassan, "The Jurisprudence of Financial Transactions (Fiqh Mu 'âmalât)," dalam Ausaf Ahmad dan Kazim Raja Awan (ed.), Lectures on Islamic Economics (Jeddah: Islamic Research and Training Institute, Islamic Development Bank, 1992), h. 107; Abdul Aziz Masyhuri, Masalah Keagamaan Hasil Muktamar dan Munas Ulama Nahdhatul Ulama (Surabaya: PP Rabithah Ma` ahidil Islamiyah dan Dinamika Press, 1977), h. 146-147; PB Mathla'ul Anwar, Keputusan-Keputusan Majelis Fatwa Mathla 'ul Anwar (Jakarta: Sekretariat PB Mathla 'ul Anwar, 1985), h. 27; MUI Pusat, "Keputusan Ijtima Ulama Komisi Fatwa se-Indonesia tentang Fatwa Bunga (Interest/Fa'idah), Terorisme, dan Penetapan Awal Ramadhan, Syawal, dan Dzulhijjah, Jakarta," (16 Dember 2003); M. M. Metwally, Principles of Islamic Economics (Australia: Departement of Economics University of Wollongong, t.th.), h. 16; dan Irfan Ul Haq, Economic Doctrines of Islam: A Study of Doctrines of Islam and Their Implications for Poverty, Employment, and Economic Growth (USA: International Institute of Islamic Thought, 1996), h. 131-132.

${ }^{10}$ Undang-Undang Nomor 21 tahun 2008 tentang Perbankan Syariah, pasal 1, angka 7, 8, 9, dan 10 . 
Penghimpunan dana di Bank Syariah dilakukan dengan akad wadî‘ah atau akad mudhârabah dalam bentuk giro, tabungan, atau bentuk lainnya yang dipersamakan dengan itu. ${ }^{11}$ Istilah penghimpunan dana bagi bank syariah dalam Undang-Undang Nomor 21 Tahun 2008 adalah investasi, yaitu dana yang dipercayakan oleh Nasabah kepada Bank Syariah dan/atau UUS berdasarkan akad mudhârabah atau akad lain yang tidak bertentangan dengan prinsip syariah.

Penyaluran dana bank (financing) disebut pembiayaan, yaitu penyediaan dana atau tagihan yang dipersamakan dengan itu berupa sejumlah hal berikut. Pertama, transaksi bagi hasil dalam bentuk mudhârabah dan musyârakah. Kedua, transaksi sewa menyewa dalam bentuk ijârah atau sewa beli dalam bentuk ijârah muntahiya bi al-amlîk. Ketiga, transaksi jual beli dalam bentuk piutang murâbahah, salam, dan istishnâ. Keempat, transaksi pinjam meminjam dalam bentuk piutang qardh. Kelima, transaksi sewa menyewa jasa dalam bentuk ijârah untuk transaksi multijasa, berdasarkan persetujuan atau kesepakatan antara Bank Syariah dan/atau Unit Usaha Syariah dan pihak lalin yang mewajibkan pihak yang dibiayai dan/atau diberi fasilitas dana untuk mengembalikan dana tersebut setelah jangka waktu tertentu dengan imbalan ujrah, tanpa imbalan, atau bagi hasil. ${ }^{12}$

Sumber hukum tidak tertulis dalam mengoperasikan perbankan syariah adalah fatwa DSN-MUI. Fatwa DSN-MUI sampai dengan bulan Mei 2013 berjumlah 87 buah. Pada umumnya, fatwa tersebut terkait dengan perbankan syariah, selain itu ada juga fatwa tentang perasuransian syariah, pasar modal syariah, pegadaian syariah, dan industri syariah lainnya. Empat fatwa DSN yang terbaru adalah fatwa Nomor: 84/DSN-MUIIXII/2012 tentang Metode Pengakuan Keuntungan al-Tamwil bial-Murâbahah (Pembiayaan Murâbahah) di Lembaga Keuangan Syariah; fatwa Nomor: 85/DSN-MUI/XII/2012 tentang Janji (wa'd) dalam Transaksi Keuangan dan Bisnis Syariah; fatwa Nomor: 86/DSN-MUI/XII/2012 tentang Hadiah dalam Penghimpunan Dana Lembaga Keuangan Syariah; dan fatwa Nomor: 87/ DSN-MUI/XII/2012 tentang Metode Pengaturan Pendapatan dan Cadangan Penyesuaian Keuntungan (Profit Equalization Reserve) dalam Bagi Hasil Dana Pihak Ketiga.

\footnotetext{
${ }^{11}$ Tabungan adalah simpanan berdasarkan akad wadi'ah atau investasi dana berdasarkan akad mudhârabah atau akad lain yang tidak bertentangan dengan prinsip syariah yang penarikannya hanya dapat dilakukan menurut syarat dan ketentuan tertentu yang disepakati, tetapi tidak dapat ditarik dengan cek, bilyet giro, dan/atau alat lainnya yang dipersamakan dengan itu. Deposito adalah Investasi dana berdasarkan akad mudhârabah atau akad lain yang tidak bertentangan dengan prinsip syariah yang penarikannya hanya dapat dilakukan pada waktu tertentu berdasarkan akad antara nasabah penyimpan dan Bank Syariah dan/atau Unit Usaha Syariah; dan Giro adalah simpanan berdasarkan akad wadi'ah atau akad lain yang tidak bertentangan dengan prinsip syariah yang penarikannya dapat dilakukan setiap saat dengan menggunakan cek, bilyet giro, sarana perintah pembayaran lainnya, atau dengan perintah pemindahbukuan. Lihat Undang-Undang Nomor: 21 Tahun 2008 tentang Perbankan Syariah, pasal 1.

${ }^{12}$ Undang-Undang Nomor: 21 Tahun 2008 tentang Perbankan Syariah, pasal 1.
} 


\section{Konsep Hadiah dan Akad Hibah}

Terminologi "hadiah"13 dalam kegiatan penghimpunan dana Lembaga Keuangan Syariah masih memerlukan penjelasan yang lebih rinci. Dalam beberapa literatur terdapat term lain yang mirip dengan hadiah, yaitu imbalan, 'athayâ, dan bonus. Hadiah dijelaskan oleh ulama sebagai objek pemberian dari salah satu pihak (di antaranya pihak Lembaga Keuangan Syariah) kepada pihak lain (di antaranya nasabah) yang merupakan penghargaan, sementara akadnya diidentikkan dengan akad hibah. ${ }^{14}$

Terminologi lain yang berhubungan dengan terminologi hadiah adalah 'athayâ (jamak dari 'athiyah yang berakar pada kata a'tha $\hat{a}^{15}$ [berarti menyerakan harta]). 'Athayâ sering diartikan ke dalam bahasa Indonesia menjadi pemberian dan/atau bonus. Dalam praktik bisnis Lembaga Keuangan Syariah di Indonesia, dibedakan antara hadiah dengan bonus. ${ }^{16}$ Dijelaskan bahwa arti hibah, sedekah, hadiah, dan 'athiyah saling berkaitan. Dari segi tujuan, pemberian yang tujuannya untuk mendekatkan diri kepada Allah disebut shadaqah, yaitu pemberian yang tujuannya untuk melahirkan rasa hormat dan cinta disebut hadiah; dan pemberian yang tujuannnya tidak untuk mendekatkan diri kepada Allah dan tidak pula untuk melahirkan rasa hormat dan cinta, disebut hibah. Sedangkan al-'athiyah dalam sejarah diartikan sebagai pemberian seseorang kepada pihak lain pada saat pemberi sedang sakit. ${ }^{17}$

Ulama menjelaskan akad hibah dari segi empat hal. Pertama, kepindahan kepemilikan objek (mawhûb); yaitu akad hibah termasuk akad yang menyebabkan kepemilikan mawhûb berpindah dari milik wâhib menjadi milik mawhûb lah ('aqd yufid al-tamlîk). Kedua, penggantian ('iwadh), yaitu wâhib tidak memperoleh penggantian dari pihak mawhûb lah. Ketiga, waktu, yaitu akad hibah dilakukan antara wâhib dan mawhûb lahu ketika mereka hidup (hal al-hayat). Keempat, hukum, yaitu hukum melakukan hibah adalah sunah (tathawwu). Sedangkan ulama Hanabilah menambah hal yang kelima, yaitu mawhûb harus benda yang berwujud dan dapat diserahterimakan (mawjûd wa maqdûr 'alâ taslîmih). ${ }^{18}$

Dasar hukum akad hibah adalah al-Qur'an dan hadis. Di antaranya adalah Q.S. alNisâ'/4: 4 tentang kebolehan suami menerima kembali pemberian (mahar) dari istrinya,

\footnotetext{
${ }^{13}$ Hadiah dalam ilmu bisnis adalah pemberian kepada konsumen karena yang bersangkutan membeli produk tertentu. Pemberian hadiah termasuk bentuk promosi yang paling terkenal. Lihat Griffin dan Ebert, Bisnis, Vol. II, h. 125.

${ }^{14}$ 'Ala' al-Ashma' Dîn Za'tari. Fiqh al-Mu'amalat al-Maliyah al-Muqarin: Shiyaghah Jadidah wa Amtsilah Mu'ashirah (Damaskus: t.p., 2008), h. 410-411.

${ }^{15}$ Terminologi al-'athâ (baca: al-'athiyah) dalam sejarah digunakan sebagai gaji bulanan/ tahunan yang diserahkan negara kepada tentara. Lihat Rafiq Yunus al-Mishrî, Ushûl al-Iqtishâd al-Islâmî (Damaskus: Dâr al-Qalam, 2005), h. 239.

${ }^{16}$ Text Book Fiqh al-Mu'âmalat, h. 734.

${ }^{17}$ Wahbbah al-Zuhaili, al-Fiqh al-Islâmi wa Adillatuh, Vol. VI (Damaskus: Dâr al-Fikr, 2006), h. 3980 .

${ }^{18}$ Ibid., h. 3980-3981.
} 
dan Q.S. al-Baqarah/2: 177 tentang tergolongnya pemberian harta kepada pihak lain sebagai perbuatan baik (al-birr). Di antara hadis Nabi Muhammad SAW. yang menjelaskan tentang hibah adalah hadis dari Abû Hurairah, 'Abd Allâh Ibn 'Umar dan 'Aisyah yang substansinya Rasulullah SAW. memerintahkan umatnya untuk saling memberi hadiah (tahâdû) karena akan melahirkan rasa saling cinta (tahâabû). ${ }^{19}$ Lalu hadis Nabi Muhammad SAW. yang substansinya mengajarkan umatnya jangan merasa hina (rendah diri) karena memberi hadiah berupa ceker ayam kepada tetangga. ${ }^{20}$ Lalu hadis dari Ibn 'Abbâs tentang cegahan meminta kembali mawhûb, yaitu Rasulullah SAW. mengumpamakan orang yang meminta kembali mawhûb laksana anjing yang memakan kembali muntahnya (al-'â'id fîhibatihi ka al-kalb yaqi 'u tsumma ya'ûdu fi qẩihi). ${ }^{21}$ Kemudian hadis fi'liyah yang menjelaskan bahwa Rasulullah SAW. menerima hadiah dan menyerahkan `iwadh (tsawâb/ balasan). ${ }^{22}$

Rukun hibah adalah wâhib (pemberi), mawhûb lah (penerima), objek yang diberikan (mawhûb), dan akad (ijab dan qâbûl). Menurut ulama Hanafiah, rukun yang paling inti adalah akadnya. Akad hibah adalah bertemunya penawaran (ijab/offer) dari wâhib dan penerimaan (qâbûl/acceptance) dari mawhûb lah yang menggunakan kata hibah, hadiah, 'athiyah, atau nihlah. ${ }^{23}$ Tetapi, karena akad hibah termasuk akad tabrru', ulama Hanafiah menjelaskan bahwa hibah boleh dilakukan hanya dalam bentuk ucapan/perbuatan yang menunjukkan kehendak hibah dari pihak wâhib, tanpa disyaratkan adanya penerimaan (qabûl) dari pihak mawhûb lah. ${ }^{24}$

Syarat wâhib adalah cakap hukum (ahliyyat al-wujûb wa al-adâ', dan termasuk ahliyyat al-tabarru) dan berkedudukan sebagai pemilik benda yang dihibahkan. Sedangkan syarat mawhûb lah (penerima hadiah) tidak disyaratkan cakap hukum (tidak mesti termasuk

${ }^{19}$ 'Ali Fikri, Mu'âmalat al-Mâdiyah wa al-Adabiyah, Vol. II (Mesir: Musthafa al-Bâbî al-Halabi wa Awladuh, 1938), h. 160. 'Ali Fikri menjelaskan bahwa hibah dan hadiah melahirkan rasa cinta dalam hati dan dapat menghilangkan dendam dan permusuhan.

${ }^{20}$ Muhammad Ibn Isma'il al-Kahlani, Subul al-Salâm, Vol. III (Bandung: Dahlan. t.t.), h. 93.

${ }^{21}$ Al-Kahlani, Subul al-Salâm, h. 90. Dijelaskan oleh al-Sayyid Sabiq bahwa yang dimaksud haram meminta kembali hibah (baca: hadiah) adalah hibah mutlak. Sementara hibah dari orang tua kepada anaknya, dan hibah bi al-tsawab (baca: hibah bi al-'iwâdh), boleh diminta kembali apabila 'iwâdh yang diharapkan oleh muhib tidak ditunaikan oleh mawhûb lah. Lihat al-Sayyid Sabiq, Fiqh al-Sunnah, Vol. III (Beirut: Dâr al-Fikr. 1983), h. 366-367; dan Syams al-Dîn Muhammad Ibn Abi Bakr Ibn Qayyim al-Jauziyah, I'lâm al-Muwaqqi î̀n 'an Rabb al-'̂̂lamîn, Vol. II (Beirût: Dâr al-Fikr, t.t.), h. 314-316.

${ }^{22}$ Abâ Dâwud Sulaimân Ibn al-Asy'ats al-Sijistâni al-Azdari, Sunan Abî Dâwûd, Vol. III (Bandung: Dahlan, t.t.), h. 290.

${ }^{23} \mathrm{Al}-Z u h a i l i$, al-Fiqh al-Islâmi wa Adillatuh, h. 3981-3982.

${ }^{24}$ Lihat Muhammad Ibn Ahmad Ibn Rusyd al-Qurthubi al-Andalûsi, Bidâyat al-Mujtahid wa Nihâyat al-Muqtashid, Vol. II (Semarang: Toha Putra, t.t.), h. 245-248; al-Zuhaili, al-Fiqh al-Islâmi wa Adillatuh, h. 3982-3983; dan Muhammad Ibn Ahmad, Fath al-Rahîm 'ala Fiqh al-Imâm Mâlik bi al-Adillah, Vol. II (Beirût: Dâr al-Fikr, 1979), h. 157-165. 
pihak yang ahliyyat al-wujûb wa al-adâ'); dan syarat mawhûb (objek hibah) adalah setiap benda yang boleh dimiliki dan tertentu atau dapat ditentukan. ${ }^{25}$

Syarat-syarat mawhûb secara rinci adalah mawhûb harus sudah ada (wujûd) pada saat akad hibah dilakukan. Mawhûb harus termasuk benda halal (mutaqawwim). Mawhûb harus harus termasuk benda yang dapat dimiliki (mamlûkfínafsih). Mawhûb harus termasuk milik wâhib. Mawhûb harus benda yang teretntu dan bukan dari benda yang tidak berharga apabila dibagi (muharaj/mufaraj). Mawhûb harus benda yang dapat dipisahkan dari yang lain (mutamayiz 'an ghairihi). Mawhûb harus benda yang dapat dikuasai (al-qabdh) ${ }^{26}$

Hibah dibedakan menjadi dua, yakni hibah muthlaqah dan hibah muqayyadah (hibah mu'âlaqah bi syarth). Hibah yang tidak boleh diminta kembali adalah hibah muthlaqah. Hibah mu'âlaqah bi syarth antara lain berupa al-'umrâ, ${ }^{27}$ al-ruqbâ, ${ }^{28}$ dan al-mânihah ${ }^{29}$ yang hukumnya diikhtilafkan ulama.

Hibah mu'aqqayyadah (tepatnya hibah mu'âlaqah bi syarth) sangat relevan untuk dibahas karena kaitannya dengan hadiah yang diberikan oleh Lembaga Keuangan Syariah kepada nasabah termasuk dalam domain hibah mu'âlaqah bi syarth. Dalam sebuah hadis yang diriwayatkan dari Abû Hurairah dijelaskan bahwa Rasulullah SAW. bersabda, wâhib lebih berhak atas mawhûb selama belum diterima imbalannya (al-wâhib ahaqq bi hibatihi

${ }^{25}$ Isu yang berkaitan dengan mawhûb antara lain adalah mengenai benda yang dapat dibagi dan tidak dapat dibagi. Hibah sebagian rumah yang luas yang tidak merusak fungsinya boleh hukumnya; akan tetapi, objek hibah yang berupa rumah yang kecil (baca: sempit) yang dapat merubah fungsinya jika dibagi, ulama berbeda pendapat (ikhtilâf); ulama Malikiah, Syafiiiah, dan Hanabilah membolehkannya; sedangkan ulama Hanafiah tidak membolehkannya. Lihat al-Zuhaili, al-Fiqh al-Islâmi wa Adillatuh, h. 3990-3991.

${ }^{26}$ Lihat al-Zuhaili, al-Fiqh al-Islâmi wa Adillatuh, h. 3988-3995.

${ }^{27}$ Al-'umrâ adalah pemberian manfaat benda dari pihak wâhib kepada pihak mawhûb lah selama mawhûb lah hidup. Apabila mawhûb lah meninggal, mawhûb harus dikembalikan kepada wâhib. Al-Zuhaili, al-Fiqh al-Islâmi wa Adillatuh, h. 3986. Pemberian berupa 'umra diikhtilafkan hukumnya oleh ulama karena menyangkut kepemilikan mawhûb: apakah kepemilikan mawhûb berpindah dari wâhib kepada mawhûb lah atau tidak? Jika kepemilikan mawhûb tidak berpindah (tetap milik wâhib), maka akad hibah tersebut secara substansi sama dengan akad al-'âriyah (hibat al-manaf); yaitu akad hibah manfaat suatu benda tanpa menghibahkan objeknya. Apabila dihubungkan dengan meninggalnya wâhib, maka mawhûb berubah menjadi tirkah (berpindahnya kepemilikan dari wâhib kepada ahli warisnya); maka sepantasnya al-umrâ berakhir karena harus digunakan untuk keperluan mayat dan sisanya dibagikan kepada ahli waris.

${ }^{28} \mathrm{Al}$-ruqbâ adalah sepakatnya pihak wâhib dengan pihak mawhûb lah bahwa apabila wâhib atau mawhûb lah meninggal, maka mawhûb menjadi milik yang masih hidup. Ulama Hanafiah dan Malikiah melarang terjadinya al-ruqbâ, tetapi mereka mengakui keabsahan al-'umrâ. Lihat al-Zuhaili, al-Fiqh al-Isâmi wa Adillatuh, h. 3986.

${ }^{29} \mathrm{Al}$-manihah berhubungan dengan objek hibah (mawhûb); al-mânihah sama dengan al'âriyah, karena itu, objeknya harus benda yang tidak habis sekali pakai. Mawhûb yang habis sekali pakai atau habis/rusak karena dipakai hanya dapat dijadikan objek hibah; mawhûb yang tidak habis sekali pakai (seperti kendaraan dan rumah) dapat dijadikan objek al-'âriyah. Sedangkan menghibahkan manfaat dinar (baca: uang) disebut akad qardh. Lihat al- Zuhaili, al-Fiqh al-Isâmi wa Adillatuh, h. 3986. 
ma lam yutsab minha). Hadis tersebut merupakan dasar dibolehkannya meminta kembali mawhûb selama imbalannya ('iwadh) belum diterima wâhib, meskipun mawhûb sudah dikuasai (qabdh) oleh mawhûb lah. Tetapi, ulama berpendapat meminta kembali mawhûb dihukumi makruh karena meminta kembali mawhûb tidaklah sah kecuali atas dasar rela atau keputusan kadhi. Karena itu, pengambilan kembali mawhûb atas dasar kerelaan para pihak termasuk iqâlah. ${ }^{30}$

\section{Mempertimbangkan Jâ'izah Tasjî́iyah}

Terminologi baru yang dikenalkan dalam penyerahan hadiah adalah jâ’izah (jawa'iz, jamak). Arti al-jâ'izah secara etimologis adalah al-'athiyah ('athayâ, jamak; pemberian). Konsep al-'athiyah berhubungan dengan domain lain. Pertama, al-'athiyah yang dihubungkan dengan domain ihssân berarti al-mukafa'ah, yaitu membalas kebaikan pihak lain dengan balasan yang setimpal (bimitslih) atau lebih baik (biziyadah). Kedua. Al-'athiyah yang dihubungkan dengan domain tha'ah berarti al-tsawâb (ganjaran/pahala). Ketiga. Al-'athiyah yang dihubungkan dengan domain ju'alah (dalam pengertian al-wa'du bi lamal) berarti imbalan ju'alah (ju'i). ${ }^{31}$

Terminologi al-jâizah berhubungan dengan terminologi hibah (tabarru). Hamd Fâruq al-Syaikh menjelaskan, jâ’izah tasyjî‘iyah merupakan terminologi yang relatif baru. Jâ’izah tasyjî́íyah diawali janji dan/atau komitmen dari pihak tertentu yang disampaikan kepada pihak lain (baca: masyarakat umum) yang harapannya adalah agar pihak tersebut melakukan pekerjaan tertentu yang dibenarkan syariah, dan yang berhasil mengerjakan pekerjaan tersebut berhak menerima jầizah (tabarru'). Hamd Fâruq al-Syaikh menjelaskan tentang operasional jẩizah tasyjî‘iyah, yaitu di antaranya berupa "pengumuman" mengenai perlombaan (musabaqah, misalnya Perlombaan Karya Tulis Ilmiah [PKTI]) dari pihak pemerintah (atau pihak bank) kepada masyarakat (atau nasabah), dan pihak yang berhasil berhak mendapatkan hadiah. ${ }^{32}$

Pada prinsipnya, ulama berpendapat bahwa jâ’izah tasyjî́iyah boleh dilakukan dengan syarat telah dipenuhi ketentuan umum dan ketentuan khususnya. Ketentuan umumnya adalah sebagai berikut. Pertama, jâ'izah tasyjî́iyah harus terhindar dari qimar

${ }^{30}$ Al-iqâlah adalah "mengurungkan" menidakjadikan, atau membatalkan; karena itu, substansi iqalah di sini adalah keridhaan dari pihak mawhûb lah atas diambilnya kembali oleh mawhûb berarti membatalkan hibah yang dilakukan oleh wâhib. Lihat al-Zuhaili, al-Fiqh al-Islâmi wa Adillatuh, h. 4004.

${ }^{31}$ Ahhmad Ahmad al-Sa'd, "al-Jawâ’iz al-Tasyjiiiyyah fî al-Bunûk al-Islâmiyyah: Dirâsah Hâlat al-Bunk al-Islâmi al-Ardâni," (Tesis: Universitas Yarmuk, 2001), h. 2, 5-6. Al-Thâlib Hamd Fâruq al-Syaikh menjelaskan bahwa terminologi al-jawa'iz berhubungan dengan terminlogi al-mukafa'ah, al-ajr (baca: ujrah), al-jazâa' (balasan), hadiah, dan hibah. Lihat Hamd Fâruq al-Syaikh, "al-Rusum wa al-Gharamat wa al-Jawa'iz fî al-Mu'assasat al-Mâliyah al-Islâmiyyah (fî̀ Dhaw' al-Syarî‘ah alIslâmiyyah)" (Tesis: Fakultas Imam al-Auza'i li al-Dirasat al-Islamiyyah. 2012), h. 123-124.

${ }^{32} \mathrm{Al}$-Syaikh, al-Rusum wa al-Gharamat, h. 122. 
(judi) dan maisir (untung-untungan). Kedua.jẩizah tasyjî̀iyah harus terhindar dari gharar. Ketiga, jâ’izah tasyjı̂‘iyah harus terhindar dari riba. Keempat, jầizah tasyjî‘iyah harus terhindar dari menggunakan/mengkonsumsi harta pihak lain secara batil. Sedangkan ketentuan khususnya adalah sebagai berikut. Pertama, jâ'izah tasyjî́íyah mengharuskan pihak peserta (baca: nasabah) mengerjakan pekerjaan yang mubah (boleh secara syariah). Kedua,jầizah tasyjî'iyah (baca: hadiah) haruslah benda yang halal. Ketiga, jâ'izah tasyjî́'iyah haruslah benda yang sudah menjadi milik pemberi (baca: Lembaga Keuangan syariah). ${ }^{33}$ Keempat, jâ’izah tasyjî́íyah haruslah benda yang berwujud. Kelima, jâ’izah tasyjî́iyah haruslah benda yang sudah diketahui secara pasti (empirik dan terukur). ${ }^{34}$

Jâ'izah tasyjî́'iyah pada operasionalnya diawali dengan komitmen yang berupa "janji melalui media tertentu agar pihak lain (baca: nasabah) melakukan perbuatan mubah tertentu, dan yang berhasil melakukannya berhak mendapatkan jầizah (hadiah) baik secara langsung maupun dengan cara-cara lain yang dibenarkan syariah (misalnya dengan cara pengundian/tasyjî́iyah), sebagaimana Yâsir Dâwûd Sulaimân Manshûr menjelaskan bahwa tasyjî́ciyah dipraktikkan dalam mu'amalah maliyah. ${ }^{35}$

${ }^{33}$ Lihat Abd Allah Khalid Abd al-Mun'im, "al-Takyif al-Fiqhi li Jawa'iz Hisabat al-Tawafir," dalam munem79@hotmail.com diakses tanggal 15 Oktober 2012.

${ }^{34}$ Al-Syaikh, al-Rusum wa al-Gharamat, h. 126-129. Lihat pula "Hukm Jawa'iz al-Bunuk al-Islamiyyah," dalam http://www.islamweb.net/fatwa/index.php?page=showfatwa\&Option= fatwaId\&Id=3720 diakses tanggal 15 Oktober 2012; "Hukm al-Hadaya al-Tasyji'iyyah al-lati Taqdimuha al-syirkat," dalam http:// www.islamweb.net/fatwa/index.php?page=showfatwa\& Option=fatwaId\&Id=145749 diakses tanggal 15 Oktober 2012; "Hukm al-Jawa'iz al-Tasyji'iyyah li Ashhab al-Mahalat wa al-Musytarin," dalam http:// www.islamweb.net/fatwa/index.php?page= showfatwa\&Option =fatwaId\&lang=A\&Id=138383 diakses tanggal 15 Oktober 2012; "Hukm Jawa'iz Musabaqat al-Jara'id wa al-Majalat," dalam http://www.islamweb. net/fatwa/index. php?page $=$ showfatwa\&Option $=$ fatwaId\&lang $=\mathrm{A} \& I d=1243$ diakses tanggal 15 Oktober 2012; "Hukm al-Jawa'iz al-lati Tamnahuha al-Mahalat li al-Zaman," dalam http://www.islamweb. net/ fatwa/index.php?page $=$ showfatwa\&Option $=$ fatwaId\&Id $=127641$ diakses tanggal 15 Oktober 2012; "al-Hibah aw al-Ja'izah ala Istihdam al-Fiza al-Ribawiyah Mal Muharam," dalam http:// www.islamweb.net/fatwa/index.php?page=showfatwa\&Option = fatwaId\&Id=169107 diakses tanggal 15 Oktober 2012; “Tabarru' li Jam'iyyah Farih Sayarah," dalam http://www. islamweb.net/ fatwa/index.php? page $=$ showfatwa\&Option $=$ fatwaId\&Id $=156573$ diakses tanggal 15 Oktober 2012; "Hukm al-Jawa'iz al-lati Tarshuduha al-Mahalat al-Tijariyah wa Hukm al-Isytirak fiha," dalam http://www.islamweb.net/fatwa/index.php?page=showfatwa\&Option= fatwaId\&lang= A\&Id=3817 diakses tanggal 15 Oktober 2012; "Jawa'iz al-Bunuk fi Minzhar al-Syar'," dalam http://www.islamweb.net/fatwa/index.php?page $=$ showfatwa\&Option $=$ fatwaId\&Id $=96428$ diakses tanggal 15 Oktober 2012; "Hukm al-Hadaya al-Tasyji'iyyah al-lati Yuqaddimuha alBunk li al-Muwadi'in," dalam http://www.islamweb.net/fatwa/index.php? page=showfatwa\& Option=fatwaId\&lang =A\&Id = 47146 diakses tanggal 15 Oktober 2012; dan "Jawa'iz Hisabat al-Tawfir fi al-Bunuk," dalam http://www.yasaloonak.net/ 2008-09-18-36-26/ 2009-07-07-1225-03/1012.html diakses tanggal 15 Oktober 2012.

${ }^{35}$ Yasir Dawud Sulaiman Manshur, Ahkâm al-Qur'ah fĩal-Fiqh al-Islâmi (Palestina: Universitas Nasional al-Najah. 2000), h. 90-96. 


\section{Relevansi Jâ'izah Tasyjî'iyah dengan Produk LKS dari Segi Akad}

Fatwa DSN-MUI yang berkaitan dengan penghimpunan dana ada tiga. Pertama, fatwa nomor: 01/DSN-MUI/IV/2000 tentang Giro. Kedua, fatwa nomor: 02/DSN-MUI/ IV/2000 tentang Tabungan. Ketiga, fatwa nomor: 03/DSN-MUI/IV/2000 tentang Deposito. Dari fatwa itu tergambar bahwa penghimpunan dana Lembaga Keuangan Syariah adalah berupa giro, tabungan, dan deposito.

Akad yang terdapat dalam produk penghimpunan dana Lembaga Keuangan Syariah dibedakan menjadi dua, yakni akad wadî‘ ah (titipan), dan akad mudhârabah. Tiga produk penghimpunan dana Lembaga Keuangan Syariah dilihat dari segi akad yang digunakan dibedakan menjadi lima yaitu giro wadî‘ $a h$, giro mudhârabah, tabungan wadî‘ $a h$, tabungan mudhârabah, dan deposito mudhârabah.

Akad wadî‘ah yang terdapat dalam produk penghimpunan dana Lembaga Keuangan Syariah merupakan akad yang di dalamnya terdapat izin dari pemilik bagi penerima titipan (Lembaga Keuangan Syariah) untuk menggunakan uang yang dititipkan. Dari segi teori tahawwul al-'aqd, ${ }^{36}$ akad wadî‘ $a h$ yang di dalamnya terkandung izin penggunaan objek wadî‘ $a h$ dari penitip kepada penerima titipan, secara substantif sama dengan akad qardh. ${ }^{37}$ Karenanya, diberlakukanlah kaidah-kaidah akad qardh yang antara lain berupa cegahan adanya imbalan yang diperjanjikan di awal akad karena termasuk riba qardh. ${ }^{38}$ Karena itu, tidaklah relevan jikajâ’izah tasyjî‘iyah digunakan untuk mempromosikan/memasarkan produk tabungan wadî‘ $a h$ dan giro wadî‘ $a h$; karena secara substantif akad yang digunakan adalah akad qardh yang termasuk dalam domain akad tabarru' ${ }^{39}$

Akad mudhârabah termasuk akad mu'âwadhat (tijârî/bisnis). ${ }^{40}$ Karenanya, jâ'izah

\footnotetext{
${ }^{36}$ Lihat antara lain 'Ali Ibrâhim al-Rasyid, al-Tahawul fí al-Asyya' wa al-Tasharrufat wa al'Uqûd wa Atsaruhu fi al-Hukm al-Syar'i (Kairo: Universitas Kairo. 2001); dan Ibrâhîm Ibn 'Abd al-Rahmân Ibn Sa'd al-Suhaili, Tahawwul al-Aqd: Dirâsah Muqâranah (Saudia Arabia: Universitas Imam Muhammad Ibn Sa'ud al-Islamiyah, $1425 \mathrm{H}$ ).

${ }^{37}$ Pernyataan bahwa wadhî‘ $a h$ dalam akad tabungan dan giro (hisâbat al-mashârif) secara hukum sama dengan akad qardh dapat dilihat pada Hanan Binti Muhammad Husen Jistaniyah, Aqsâm al-'Uqûd fî al-Fiqh al-Islâmi (Saudi Arabia: Universitas Umm al-Qura. 1999), tesis magister, h. 115; lihat Himpunan Fatwa Dewan Syariah Nasional MUI (Jakarta: DSN-MUI dan Bank Indonesia, 2006), h. 467-468. Terminologi lainnya adalah al-wadîah al-istitsmâriyah. Lihat Badr Ibn 'Alî Ibn 'Abd Allâh al-Zamil, al-Hiisâbat al-Istitsmâriyah ladai al-Mashârif al-Islâmiyyah (Riyadh: Dâr Ibn al-Jauzi, 1431 H), h. 55; dan Nazih Hammad, 'Aqd al-Wadîah fí al-Syarî́ah al-Islâmiyah (Damaskus: Dâr al-Qalam, 1993), h. 89-131.

${ }^{38}$ Dengan mengutif pendapat Ustaz al-Jawahiri, Rafiq Yunus al-Mishrî menyebut riba alqardh sebagai risiko, yaitu risiko qardh yang ribawi. Lihat Rafiq Yûnus al-Mishrî, Buhûts fĩ al-Iqtishâd al-Islâmi (Damaskus: Dâr al-Maktabi, 2009), h. 117.

${ }^{39} \mathrm{Di}$ antara ulama yang memperkenalkan akad dari segi tujuannya dibedakan menjadi akad tabarru' dan akad mu'âwadhat adalah Rafiq Yûnus al-Mishrî. Lihat Rafiq Yûnus al-Mishrî, Fiqh al-Mu'âmalat al-Mâliyah (Damaskus: Dâr al-Qalam, 2007), h. 165, 237.

${ }^{40}$ Penjelasan rinci mengenai akad mudhârabah antara lain dapat dilihat dalam Muhammad 'Abd al-Mun'im Abû Zaid, Nahw Tathwîr Nizhâm al-Mudhârabah fì al-Mashârif al-Islâmiyyah
} 
tasyjî́iyah relevan digunakan untuk memasarkan/mempromosikan produk penghimpunan dana Lembaga Keuangan Syariah yang berupa giro mudhârabah, tabungan mudhârabah, dan deposito mudhârabah.

\section{Isu Qimar dan Tasyjî́iyah dalam Menentukan Hadiah}

Kajian tentang qimar dan/atau tasyjî́iyah berkaitan dengan cara menentukan hadiah (jầizah tasyjî̌iyah). Apabila hadiah ditentukan secara langsung, maka tidak terkait dengan isu qimar dan tasyjî́iyah. Umpamanya pihak Lembaga Keuangan Syariah berkomitmen untuk memberikan hadiah berupa sepeda motor merek tertentu kepada setiap yang menyimpan dana dalam bentuk giro/tabungan/deposito mudhârabah dengan jumlah minimal 1 milyar dalam jangka waktu minimal 6 bulan, maka Lembaga Keuangan Syariah secara langsung menyerahkan hadiah berupa sepeda motor kepada nasabah pada saat nasabah telah melakukan perbuatan mubah yang diharapkan oleh Lembaga Keuangan Syariah.

Di antara hal yang menarik didiskusikan adalah sebagai berikut. Pertama, isu tentang kesempurnaan pekerjaan (al-natijah al-tammah atau al-a'mal al-tam); apakah hadiah boleh diserahterimakan pada saat nasabah mulai menabung dengan jumlah tabungan 1 milyar (misal) sebelum jangka waktunya berakhir (6 bulan), atau penyerahan hadiah hanya boleh dilakukan apabilan jumlah tabungan minimalnya terpenuhi (misal 1 milyar) dan jangka waktu penyimpanan (6 bulan) telah dijalani. Dengan mempertimbangkan daya saing Lembaga Keuangan Syariah, maka mestinya serahterima hadiah boleh dilakukan sebelum jangka waktunya berakhir, dengan syarat terdapat janji dari pihak nasabah untuk menyempurnakan jangka waktu minimal penyimpanannya.

Kedua, isu undian (tasyjî́ciyah), ${ }^{41}$ yaitu pengundian bagi setiap pihak yang melakukan penyimpanan dana giro/tabungan/deposito mudhârabah dalam jumlah tertentu dengan jangka waktu tertentu berhak untuk diundi dalam rangka mendapat "hadiah" berupa paket perjalanan umrah (misalnya). Hadiah yang disediakan berjumlah 10 paket untuk 10 pemenang, sementara jumlah penabung yang berhasil melakukan prestasi yang diharapkan Lembaga Keuangan Syariah misalnya mencapai 3000 orang. Dalam contoh yang kedua ini, pengundian boleh dilakukan dengan syarat dilakukan secara transparan dan dianjurkan melibatkan pihak yang berwenang agar terhindar dari selisih/sengketa.

(Kairo: al-Ma'had al-'Alami li al-Fikr al-Islâmi. 2000); dan Muhammad Shalah Muhammad alShâwî, Musykilât al-Istitsmâr fí al-Bunuk al-Islâmiyah wa Kaifa 'Alajaha al-Islâm (Kairo: Dâr al-Wafa', 1990), h. 19-111.

${ }^{41}$ Bacaan lebih lanjut yang relevan adalah Yasir Dâwud Sulaimân Manshûr, Ahkkâm alQur'ah fí al-Fiqh al-Islâmi (Palestina: Universitas Nasional al-Njah, 2000); Sulaimân Ibn Ahmad al-Mulhim, al-Qimar: $\underline{H} a q i \hat{q} q a t u h u$ wa Ahkamuhu (Riyadh: Dâr Kunuz Isybiliya, 2008); dan Rafiq Yûnus al-Mishrî, al-Maisir wa al-Qimar: al-Musâbaqat wa al-Jawâiz (Damaskus: Dâr al-Qalam, 1993). 


\section{Hadiah dan Risywah}

Majelis Ulama Indonesia dalam Musyawarah Nasional VI Tahun 2000 telah menetapkan fatwa tentang risywah (suap), ghulul (korupsi) dan hadiah kepada pejabat. Fatwa ini terkait dengan isu hadiah dalam produk penghimpunan dana Lembaga Keuangan Syariah.

Dalam fatwa tersebut dijelaskan empat hal. Pertama, risywah adalah pemberian yang diberikan oleh seseorang (baca: pihak) kepada pihak lain dengan maksud meluluskan suatu perbuatan yang batil atau membatilkan perbuatan yang hak. Kedua, suap/uang pelicin/money politic dapat dikategorikan sebagai risywah apabila tujuannya untuk meluluskan sesuatu yang batil atau membatilkan sesuatu yang hak. Ketiga, hadiah adalah suatu pemberian dari satu pihak kepada pihak lain karena penghormatan. Keempat, korupsi adalah tindakan pengambilan sesuatu yang ada di bawah kekuasaannya dengan cara yang tidak sah menurut syariat Islam.

Setelah menjelaskan definisi-definisi tersebut, ditetapkan tiga hal. Pertama, hukum memberikan risywah dan menerimanya adalah haram. Kedua, hukum melakukan korupsi adalah haram. Ketiga, hukum memberikan hadiah adalah 1) jika pemberian hadian tidak terkait dengan kekuasaan dan jabatan seseorang, maka hukum memberi dan menerima hadiah adalah tidak haram; 2) jika antara pemberi hadiah dengan penerima hadiah (pejabat) tidak ada atau tidak akan ada urusan apa-apa, memberikan dan menerima hadiah tersebut tidaklah haram; 3) jika antara pemberi hadiah dengan penerima hadiah (pejabat) terdapat urusan (perkara), maka bagi pejabat haram menerima hadiah tersebut; dan bagi pemberi, haram memberikannya apabila pemberian dimaksud bertujuan untuk meluluskan sesuatu yang batil (bukan haknya); dan 4) jika antara pemberi dan penerima hadiah (pejabat) ada suatu urusan, dan pemberian hadiah tidak bertujuan untuk sesuatu yang batil, maka halal (tidak haram) bagi pemberi memberikan hadiah tersebut, tetapi bagi pejabat haram menerimanya. ${ }^{42}$

Fatwa MUI tentang Risywah (suap), ghulul (korupsi) dan hadiah kepada pejabat, secara tidak langsung berhubungan dengan imbalan ju'alah yang sedang dikaji dan didiskuskan. Dalam fatwa tersebut dipersamakan antara "meluluskan sesuatu yang batil" dengan "bukan haknya." ${ }^{43}$ Kata kunci "bukan haknya" dapat jelaskan sebagai berikut.

${ }^{42}$ Ketentuan nomor empat berkaitan dengan suap yang dilakukan oleh pihak tertentu agar penerima suap (pihak otoritas) berhenti melakukan kezaliman; suap tersebut tujuannya baik, yaitu sebagai bagian dari upaya mengimplementasikan keadilan; maka memberi suap hukumnya boleh, tapi hukum menerimanya adalah haram. Lihat Za'tari, Fiqh al-Mu'âmalat, h. 348.

${ }^{43}$ Ulama menjelaskan bahwa risywah dibedakan menjadi empat bentuk: 1) penyuap menyerahkan suap kepada pihak lain dengan harapan pihak penerima dapat menyerahkan suatu benda/ pelayanan yang bukan haknya kepada penyuap; 2) penyuap menyerahkan suap kepada pihak lain dengan harapan agar penerima meniadakan hak pihak lain karena penyuap dihinggapi penyakit dengki; 3) penyuap menyuap pihak tertentu agar pihak penerima suap menyerahkan pekerjaan meskipun tidak sesuai dengan kapasitas/kompetensinya; dan 4) penyuap menyuap pihak otoritas agar hak penyuap berjalan secara baik. Lihat Za'tari, Fiqh al-Mu'âmalat, h. 347. 
Pertama, pejabat yang menyimpan dana milik kantor ataun perusahaan yang berada di bawah kekuasannya pada Lembaga Keuangan Syariah dalam bentuk tabungan mudhârabah, giro mudhârabah, atau tabungan mudhârabah, tidak berhak mendapatkan hadiah/imbalan ju'alah dan/atau bagi hasil dari tabungan/deposito/giro mudhârabah secara pribadi; hadiah/ imbalan ju'alah dan/atau bagi hasil mudhârabah harus diakui/dibukukan sebagai pendapatan kantor atau perusahaan (bukan menjadi milik pribadi).

Kedua, dana haji setoran BPIH yang termasuk daftar tunggu dalam fatwa MUI ditetapkan sebagai dana milik calon haji. Karena itu, pejabat yang menyimpan dana tersebut tidak berhak mendapatkan hadiah/imbalan ju'alah dan/atau bagi hasil dari simpanan mudhârabah secara pribadi. Hadiah/imbalan ju'alah dan/atau bagi hasil dari tabungan/giro/deposito mudhârabah harus dibukukan sebagai pendapatan calon jamaah haji yang bersangkutan (bukan menjadi milik pejabat). ${ }^{44}$

\section{Ragam Hadiah dalam Praktik di Perbankan Syariah}

Hadiah merupakan bagian integral dari promosi/pemasaran produk industri, termasuk industri keuangan syariah. Griffin dan Ebert menegaskan bahwa hadiah dalam ilmu bisnis merupakan bentuk promosi yang paling terkenal. Berdasarkan wawancara dengan sejumlah pegawai bank syariah, dapat dijelaskan ragam hadiah yang diberikan bank syariah kepada nasabah dan disederhanakan menjadi lima corak berikut. ${ }^{45}$ Pertama, undian, yang dimaksud undian di sini adalah menyangkut cara (metode) penentuan pihak atau pihak-pihak yang berhak mendapatkan hadiah. Pada umumnya, undian dilakukan terhadap pemilik dana pihak ketiga yang tabungan/deposito/gironya mencapai jumlah tertentu dan pada jangka waktu tertentu berhak diundi untuk mendapatkan hadiah tertentu yang pada umumnya bersifat material (seperti hadiah umrah atau kendaraan roda empat/ roda dua). Kedua, gimik/langsung, yaitu hadiah yang diberikan bank kepada setiap pihak yang membuka rekening (baru) tabungan/deposito/giro; pada umumnya hadiah bersifat immaterial (seperti hadiah berupa paying, pulpen, topi, dan/atau kaos). Ketiga, individual, yaitu hadiah yang dijanjikan bank hanya kepada nasabah tertentu; atau nasabah yang diminta menempatkan dananya di bank meminta hadiah kepada bank. Pada umumnya, hadiah yang bercorak individual ini bersifat material. Keempat, bonus ('athayâ), yaitu hadiah yang diberikan bank kepada nasabah yang menyimpan dananya di bank berupa tabungan atau giro wadî ' $a h$. Pada umumnya bonus bersifat immaterial. Kelima, discount, yaitu pemberian hadiah dari bank kepada nasabah yang berupa potongan kewajiban pembayaran karena melakukan pelunasan sebelum jatuh tempo. Dari sudut bank, corak discount

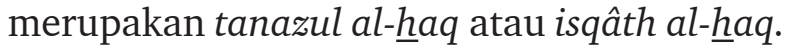

${ }^{44}$ Lihat M. Ichwan Sam, et al. (peny.), Himpunan Keputusan Ijtima' Ulama Komisi Fatwa seIndonesia IV Tahun 2012 (Jakarta: Majelis Ulama Indonesia, 2012), h. 98-103.

${ }^{45}$ Wawancara dengan pegawai Perbankan Syariah bulan Oktober 2012 di Jakarta. 
MIQOT Vol. XXXVII No. 2 Juli-Desember 2013

\section{Penutup}

Berdasarkan deskripsi di atas, dapat disimpulkan sebagai berikut. Pertama, hadiah yang ditawarkan sebagai upaya pemasaran produk penghimpunan dana Lembaga Keuangan Syariah hanya relevan dengan produk penghimpunan dana yang menggunakan akad mu'âwadhat, yaitu giro mudhârabah, tabungan mudhârabah, dan depositi mudhârabah . Karenanya, promosi produk mudhârabah yang menggunakan jầizah tasyjî‘iyah tidak relevan dengan produk penghimpunan dana Lembaga Keuangan Syariah yang menggunakan akad wadî' ah yang di dalamnya terkandung izin untuk menggunakan uang yang dititipkan, karena wadî $a h$ tersebut secara substantif sama dengan akad qardh yang tidak termasuk akad mu'âwadhat.

Kedua, pihak yang berhak menerima hadiah (gift) adalah pihak penyimpan sekaligus pemilik dana yang disimpan dalam bentuk tabungan/giro/deposito mudhârabah. Karena itu, pejabat yang menempatkan dana kantor/perusahaan tempatnya bekerja, tidak berhak mendapat hadiah. Hadiah adalah milik kantor/perusahaan yang bersangkutan (bukan milik pribadi), kecuali hadiah tersebut bersifat immaterial. Ketiga,jẩizah tasyjî́iyah pada prinsipnya tidak hanya dapat digunakan dalam promosi/pemasaran produk penghimpunan dana Lembaga Keuangan Syariah. Tetapi, jâ'izah tasyjî́iyah dapat diimplementasikan dalam produk penyaluran dana, terutama apabila hadiah diharapkan dapat mengakibatkan disiplinnya nasabah Lembaga Keuangan Syariah dalam mengembalikan dana milik Lembaga Keuangan Syariah.

\section{Pustaka Acuan}

Abû Zaid, Muhammad 'Abd al-Mun'im. Nahw Tathwîr Nizhâm al-Mudhârabah fî alMashârif al-Islâmiyyah. Kairo: al-Ma'had al-'Alami li al-Fikr al-Islâmi, 2000.

Al-Azdari, Abâ Dâwud Sulaimân Ibn al-Asy’ats al-Sijistâni. Sunan Abî Dâwûd. Vol. III. Bandung: Dahlan, t.t.

Al-Andalûsi, Muhammad Ibn Ahmmad Ibn Rusyd al-Qurthubi. Bidâyat al-Mujtahid wa Nihâyat al-Muqtashid. Vol. II. Semarang: Toha Putra, t.t.

'Abduh, Isa. Bunuk bila Fawa’id. Mesir: Dâr al-I` tisham. t.t.

Ahmad, Amrullah (ed.). Prospek Hukum Islam dalam Kerangka Pembangunan Hukum Nasional di Indonesia: Sebuah Kenangan 65 Tahun Prof. Dr. H. Busthaul Arifin. SH. Jakarta: IKAHA dan Gema Insani Press, 1994.

Amin, Maruf. "Pembaharuan Hukum Ekonomi Syariah dalam Pengembangan Produk Keuangan Kontemporer. Transformasi Fikih Muamalat dalam Pengembangan Ekonomi Syariah," Pidato Ilmiah pada Penganugerahan Gelar Doktor Kehormatan. Doctor Honoris Causa. dalam Bidang Hukum Ekonomi Syariah di Kampus UIN Syarif Hidayatullah Jakarta, 5 Mei 2012. 
Al-Barazi, Muhammad Fu'ad. Mas'ûliyat al-Fatwâ al-Syar'iyah wa Dhawâbituhâ wa Atsaruhâ fi Rasyad al-Ummah. t.t.p.: t.p., t.t.

Basyir, Ahmad Azhar. Hukum Islam tentang Riba, Utang-Piutang, dan Gadai. Cet. 2. Bandung: al-Ma'arif. 1983.

Coulson, N.J. A History of Islamic Law. Edinburgh: Edinburgh University Press, 1991.

Coulson, N.J. Conflicts and Tensions in Islamic Jurisprudence. Chicago \& London: The University of Chicago Press, 1969.

Daghi, Muhy al-Dîn al-Qurrah. Buhûts fĩ al-Bunûk al-Islâmî. Beirût: Dâr al-Basya'ir alIslâmiyah, 2009.

Direktori Syariah Indonesia. Jakarta: Dewan Syariah Nasional MUI, t.t.

Fikri, 'Ali. Mu'âmalat al-Mâdiyah wa al-Adabiyah. Vol. II. Mesir: Musthafa al-Bâbî alHalabi wa Awladuh, 1938.

Griffin, Ricky W., dan Ronald J. Ebert. Bisnis. Vol. II. Jakarta: Indeks, 2006.

Himpunan Fatwa Dewan Syariah Nasional MUI. Jakarta: DSN-MUI dan Bank Indonesia, 2006.

Haroen, Nasrun (ed.) Ensiklopedi Hukum Islam. Vol. I. Jakarta: Ichtiar Baru van Hoeve. 2003.

Hassan, A. Soal-Jawab tentang Berbagai Masalah Agama. Juz II. Cet. 10. Bandung: Diponegoro, 1988.

Hammad, Nazih. 'Aqd al-Wadîah fí al-Syarî‘ah al-Islâmiyah. Damaskus: Dâr al-Qalam, 1993.

"Hukm Jawa'iz al-Bunuk al-Islamiyyah," dalam http://www.islamweb.net/fatwa/index. php ? page $=$ showfatwa\&Option $=$ fatwaId $\& I d=3720$ diakses tanggal 15 Oktober 2012.

"Hukm al-Hadaya al-Tasyji'iyyah al-lati Taqdimuha al-syirkat," dalam http:// www. islamweb.net/fatwa/index.php?page = showfatwa\&Option $=$ fatwaId\&Id $=145749$ diakses tanggal 15 Oktober 2012.

"Hukm al-Jawa'iz al-Tasyji'iyyah li Ashhab al-Mahalat wa al-Musytarin," dalam http:// www.islamweb.net/fatwa/index.php?page = showfatwa\&Option = fatwaId\&lang $=$ A\&Id=138383 diakses tanggal 15 Oktober 2012.

"Hukm Jawa'iz Musabaqat al-Jara'id wa al-Majalat," dalam http://www.islamweb. net/ fatwa/index.php?page $=$ showfatwa\&Option $=$ fatwaId\&lang $=\mathrm{A} \& I d=1243$ diakses tanggal 15 Oktober 2012.

"Hukm al-Jawa'iz al-lati Tamnahuha al-Mahalat li al-Zaman," dalam http://www.islamweb. net $/$ fatwa/index.php?page $=$ showfatwa\&Option $=$ fatwaId\&Id $=127641$ diakses tanggal 15 Oktober 2012.

Hukm al-Jawa'iz al-lati Tarshuduha al-Mahalat al-Tijariyah wa Hukm al-Isytirak fiha," dalam http://www.islamweb.net/fatwa/index.php?page=showfatwa\& Option= fatwaId\&lang=A\&Id=3817 diakses tanggal 15 Oktober 2012.

"Hukm al-Hadaya al-Tasyji'iyyah al-lati Yuqaddimuha al-Bunk li al-Muwadi'in," dalam 
MIQOT Vol. XXXVII No. 2 Juli-Desember 2013

http://www.islamweb.net/fatwa/index.php?page=showfatwa\&Option $=$ fatwaId\&lang=A\&Id=47146 diakses tanggal 15 Oktober 2012.

"Al-Hibah aw al-Ja'izah ala Istihdam al-Fiza al-Ribawiyah Mal Muharam," dalam http:// www.islamweb.net/ fatwa/index.php?page =showfatwa\&Option=fatwaId\&Id $=$ 169107 diakses tanggal 15 Oktober 2012.

Hassan, Hussain Hamid. "The Jurisprudence of Financial Transactions. Fiqh Mu âmalât.," dalam Ausaf Ahmad dan Kazim Raja Awan. ed... Lectures on Islamic Economics . Jeddah: Islamic Research and Training Institute. Islamic Development Bank, 1992.

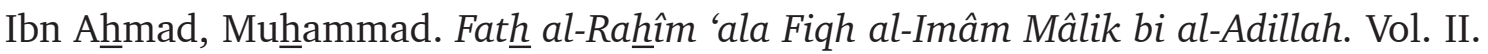
Beirut: Dâr al-Fikr, 1979.

Al-Jauziyah, Syams al-Dîn Muhammad Ibn Abi Bakr Ibn Qayyim. I'lâm al-Muwaqqi'în 'an Rabb al-'Âlamîn. Vol. II. Beirût: Dâr al-Fikr, t.t.

"Jawa'iz al-Bunuk fi Minzhar al-Syar'," dalam http://www.islamweb.net/fatwa/index. php? page $=$ showfatwa\&Option $=$ fatwaId $\& I d=96428$ diakses tanggal 15 Oktober 2012.

"Jawa'iz Hisabat al-Tawfir fi al-Bunuk," dalam http://www.yasaloonak.net/ 2008-09-1836-26/2009-07-07-12-25-03/1012.html diakses tanggal 15 Oktober 2012.

Jistaniyah, Hanan Binti Muhammad Husen. Aqsâm al-'Uqûd fì al-Fiqh al-Islâmi. Saudi Arabia: Universitas Umm al-Qura, 1999.

Al-Kahlani, Muhammad Ibn Isma'il. Subul al-Salâm. Vol. III. Bandung: Dahlan, t.t.

Karim, Adiwarman A. Bank Islam: Analisis Fiqih dan Keuangan. Jakarta: RajaGrafindo Persada, 2010.

Manshur, Yasir Dawud Sulaiman. A $\underline{h} k a ̂ m$ al-Qur'ah fî al-Fiqh al-Islâmi. Palestina: Universitas Nasional al-Najah, 2000.

Masyhuri, Abdul Aziz. Masalah Keagamaan Hasil Muktamar dan Munas Ulama Nahdhatul Ulama. Surabaya: PP Rabithah Ma'ahidil Islamiyah dan Dinamika Press, 1977.

Manshûr, Yasir Dâwud Sulaimân. A $\underline{h} k a ̂ m$ al-Qur'ah fî al-Fiqh al-Islâmi. Palestina: Universitas Nasional al-Najah, 2000.

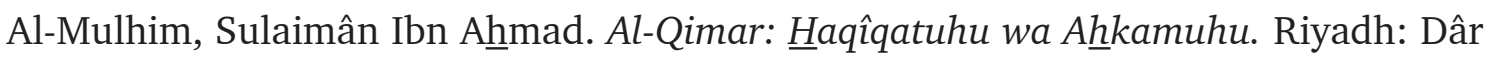
Kunuz Isybiliya, 2008.

Al-Mun'im, Abd Allah Khalid Abd. "al-Takyif al-Fiqhi li Jawa'iz Hisabat al-Tawafir," dalam munem79@hotmail.com diakses tanggal 15 Oktober 2012.

Al-Mishrî, Rafiq Yûnus. Buhûts fí al-Iqtishâd al-Islâmi. Damaskus: Dâr al-Maktabi, 2009.

Al-Mishrî, Rafiq Yûnus. Fiqh al-Mu'âmalat al-Mâliyah. Damaskus: Dâr al-Qalam, 2007.

Al-Mishrî, Rafiq Yûnus. al-Maisir wa al-Qimar: al-Musâbaqat wa al-Jawâ'iz. Damaskus: Dâr al-Qalam, 1993.

Al-Mishrî, Rafiq Yunus. Ushûl al-Iqtishâd al-Islâmî. Damaskus: Dâr al-Qalam, 2005.

Mohsen, M. "A Profile of Riba-Free Banking," dalam Mohammad Arief. (ed.), Monetary 
and Fiscal Economics of Islam. Jeddah: International Centre for Research in Islamic Economics. King Abdulaziz University, 1982.

Mudzhar, M. Atho. "Penerapan Pendekatan Sejarah Sosial dalam Hukum Islam," makalah disampaikan dalam acara diskusi yang diselenggarakan oleh Pusat Pengkajian UNISBA. di Bandung, 8 Januari 1992.

Mudzhar, M. Atho. "Fiqh dan Reaktualisasi Ajaran Islam," dalam Budhy Munawar-Rachman. (ed). Kontekstualisasi Doktrin Islam dalam Sejarah. Jakarta: Yayasan Wakaf Paramadina. 1994.

MUI Pusat. "Keputusan Ijtima Ulama Komisi Fatwa se-Indonesia tentang Fatwa Bunga. Interest/Fa'idah.. Terorisme. dan Penetapan Awal Ramadhan. Syawal. dan Dzulhijjah. Jakarta," 16 Dember 2003.

Metwally, M. M. Principles of Islamic Economics. Australia: Departement of Economics University of Wollongong, t.t.

Al-Mushlih, Khalid Abd Allah. al-Hawâfiz al-Tijâriyah al-Taswîqiyah wa Ahkâmuhâ fi alFiqh al-Islâmi. t.t.p.: t.p., t.t.

PP Muhamadiyah. Himpunan Putusan Tarjih. Yogyakarta: Pengurus Pusat Muhammadiyah Majlis Tarjih, t.t.

PB Mathla'ul Anwar. Keputusan-Keputusan Majelis Fatwa Mathla 'ul Anwar. Jakarta: Sekretariat PB Mathla`ul Anwar, 1985.

Al-Rasyid, 'Ali Ibrâhim. al-Tahawul fí al-Asyya' wa al-Tasharrufat wa al-'Uqûd wa Atsaruhu fi al-Hukm al-Syar 'i. Kairo: Universitas Kairo, 2001.

Al-Suhaili, Ibrâhîm Ibn 'Abd al-Raḩmân Ibn Sa'd. Tahawwul al-Aqd: Dirâsah Muqâranah. Saudia Arabia: Universitas Imam Muhammad Ibn Sa'ud al-Islamiyah, 1425 H.

Al-Shâwî, Muhammad Shalah Muhammad. Musykilât al-Istitsmâr fí al-Bunuk al-Islâmiyah wa Kaifa 'Alajaha al-Islâm. Kairo: Dâr al-Wafa', 1990.

Sam, M. Ichwan. et al. (peny.) Himpunan Keputusan Ijtima'Ulama Komisi Fatwa se-Indonesia IV Tahun 2012. Jakarta: Majelis Ulama Indonesia, 2012.

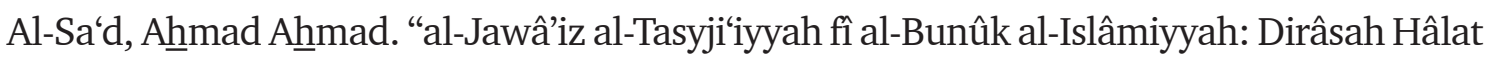
al-Bunk al-Islâmi al-Ardâni,". Tesis: Universitas Yarmuk, 2001.

Al-Syaikh, Hamd Fâruq. "al-Rusum wa al-Gharamat wa al-Jawa'iz fî al-Mu'assasat alMâliyah al-Islâmiyyah fî Dhaw’ al-Syarî‘ah al-Islâmiyyah.” Tesis: Fakultas Imam alAuza'i li al-Dirasat al-Islamiyyah, 2012.

Sabiq, Sayyid. Fiqh al-Sunnah. Vol. III. Beirût: Dâr al-Fikr, 1983.

Al-Saud, Mahmud Abu. "Islamic View of Riba: Usury and Interest," dalam Syekh Ghazali Syaikh Abod. et al. (ed.) An Introduction to Islamic Finance. Kuala Lumpur: Quill Publishers, 1992.

Schacht, Joseph. An Introduction to Islamic Law. Oxford: Oxford University Press, 1964.

Sadr, Muhammad Baqer, dan Ayatullah Sayyid Mahmud Taleghani. Islamic Economics: Contemporary Ulama Perspective. Kuala Lumpur: Iqra', 1991. 
MIQOT Vol. XXXVII No. 2 Juli-Desember 2013

Sulaiman, Thahir Abdul Muhsin. Menanggulangi Krisis Ekonomi secara Islam. terj. Anshori Umar Sitanggal. Bandung: al-Ma'arif. 1985.

Sunaryo, Oyo. "Hukum Kewarisan Islam: Formulasi Baru tentang Kewarisan Islam dalam Tata Hukum Indonesia” dalam al-Tadbir. Vol. I. No. 3. 2000.

Taizir, Aswita. "Muhammad Abduh and The Reformation of Islamic Law,". Thesis McGill University, 1994.

"Tabarru' li Jam'iyyah Farih Sayarah," dalam http://www.islamweb.net/fatwa/index. php ?page $=$ showfatwa\&Option $=$ fatwaId \&Id $=156573$ diakses tanggal 15 Oktober 2012.

Usmani, Muhammad Imran Ashraf. Meezanbank's Guide to Islamic Banking. Karachi: Darul Ishaat, 2002.

Ul-Haq, Irfan. Economic Doctrines of Islam: A Study of Doctrines of Islam and Their Implications for Poverty. Employment. and Economic Growth. USA: International Institute of Islamic Thought, 1996.

Zahrah, Muhammad Abû. Buhuts fî al-Riba. Mesir: Dâr al-Buhuts al-'Ilmiyah. 1970.

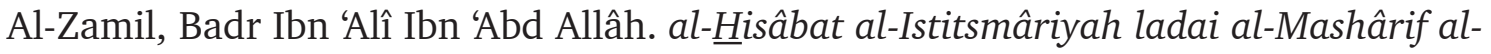
Islâmiyyah. Riyadh: Dâr Ibn al-Jauzi, $1431 \mathrm{H}$.

Za'tari, 'Ala' al-Ashma' Dîn. Fiqh al-Mu'amalat al-Maliyah al-Muqarin: Shiyaghah Jadidah wa Amtsilah Mu'ashirah. Damaskus: t.p., 2008.

Al-Zuhaili, Waḩbah. al-Fiqh al-Islâmi wa Adillatuh. Vol. VI. Damaskus: Dâr al-Fikr, 2006. 